\title{
Mouna Vratha: An Effective Traditional Method of Self-Regulation
}

\author{
Roshni $\mathrm{C}^{*}$ and J Nicolas Benedict ${ }^{\dagger}$
}

\begin{abstract}
Self-regulation is an important psychological skill that aims at self-realization and better self-actualization. Selfregulation directed towards behaviour is called behavioural self- regulation; directed towards emotions, inner states and cognitive function is known as emotional self- regulation. Most of the relationship or social issue in the western tradition is due to either of the two types of self-regulation failure-inadequate or misguided selfregulation. Mouna Vratha, the religious practice of vow of silence emphasizes that self-control is very important to be observed by a person. The use of Mouna vratha as a technique of self-regulation in counselling and psychotherapy will help an individual to explore their selves in the realm of silence. The present paper discusses the effectiveness of self-regulation and how it can be implemented through the practice of mouna vratha.
\end{abstract}

Keywords: Counselling, Mouna Vratha, Self-regulation, Selfcontrol, Self-actualisation

\footnotetext{
* Counselling psychologist, Naveen hospital for mental health and deaddiction, Coimbatore, India ; nickagamnaan@gmail.com

† Counselling psychologist, Naveen hospital for mental health and deaddiction, Coimbatore, India; roshni.bright7@gmail.com
} 


\section{Introduction}

Baumeister and Vohs (2007) defined Self-regulation as "the way that a person controls his or her own responses so as to pursue or maintain goals and live up to standards". Self-regulation directed towards behaviour is called behavioural self- regulation; directed towards emotions, inner states and cognitive function is known as emotional self- regulation. Regulating cognitive functions leads to regulation of emotions (Eisenberg \& Zhou, 2000). Though William James had explained a lot about human self, it was only around 1990 researchers began to focus on it as the important key to understand the self. However, this delay has been made up through various studies highlighting the importance of selfregulation in various fields such as emotion, mental health, aggression, decision-making, crime, etc. Without self-regulation, it is difficult to deal with both the demands and opportunity of the surroundings. Plenty research has been done on the topic of selfregulation; however, Baumeister, Heatherton and Tice (1994) found it being scattered among various disciplines and traditions and most the studies conducted were not aware of the findings of the others. Most of the relationship or social issue in the western tradition is due to either of the two types of self-regulation failureinadequate or misguided self- regulation. Inadequate selfregulation denotes insufficient attempts at self-regulation and misguided self-regulation denotes the attempts that are counterproductive and hence does not give the desired result. Selfregulation is required not only to come out of problems but also to avoid them by staying healthy and happy.

\section{Importance of self-regulation in well-being}

In a longitudinal study by Mischel, Shoda and Peake (1988) children who were able to delay gratification as early as early as 4 years were successful in their work and social lives. The ability to delay gratification is very important for self-regulation. Duckworth and Seligman (2005) found that good self-regulation leads to good academic grades, also avoiding and staying out of trouble or pathology, have better relationships and do well in sports. 


\section{Role of Religious methods in self-regulation}

McCullough \& Willoughby (2009) found that religiousness and self-regulation are highly related. They proposed that religiousness leads to self-regulation by influencing people's goals, fostering selfmonitoring and building self-regulatory strength. Religious people are likely to score more on self-control and have children who are self-controlled. They concluded by saying that religiousness in people affects health and as well as well- being through self-control and self-regulation. People who practice the religion, they believe, are more likely to have decreased anger, social isolation and hostility and increased self- esteem. (Maltby \& Day, 2000; Laurencelle, Abell \& Schwartz, 2002)

\section{Self- regulation of Senses}

McCullough \& Willoughby (2009) found that religion and selfcontrol are strongly correlated. Roy Baumeister (2012), who has studied the topic of self-esteem versus self-control for many years, believes that self-esteem does not lead to success. "Self-control is much more powerful and well-supported as a cause of personal success," he says. Self-control is a quality rooted in all religious traditions. In Hinduism, self-realization is impossible without the stability of mind. Bhagavat Gita says that pleasure from senses is like a nectar but it ends later being poison. Hence, self-control is very important to achieve self-realization. There are also various practices like the mouna vratha (vows of silence) and unna vratha (food fasting) which emphasize that self-control is very important to be observed by a person. Christianity too emphasizes the importance of self-control. The Bible says that a person without self-control is like a city where its walls are broken. The Bible also says that if one of your eyes commits sin, throw away the other eye too; it is better to live without sins than to live with two eyes. Islam also talks about self- control through the control of senses. The month of Ramzan is a month of fasting where one refrains from eating or drinking from sunrise to sunset. This helps not only in gaining self- control but also resilience. These practices ask people to delay gratification and also reduces immediate reaction to situations by helping them think and act. Baumeister (2012) uses the words self-control and self-regulation synonymously. Delay in gratification leads to self-regulation in an individual. 


\section{Self- regulation of spending behavior}

In Hinduism, the art of giving (dana) is an important aspect of dharmic life. Many Hindus are engaged in the practice of anna dana (food offering) on special occasions. The story of Ilayangudi Mara Nayanar in the Tamil literature, Periya puranam, who feeds a homeless devotee of Lord Ishwar when he did not have food for himself, is an example. In Christianity, the pupils are encouraged to give one-tenth of their income to God as an offering as well as giving an offering in the church masses every Sunday. Charity is not done out of compulsion but it is done out of divine love. Zakat is one of the pillars of Islamic practice (Mufti, 2006). The money collected through Zakat is used only for those who are in need and to free the debtors and slaves.

\section{Self- regulation of Affective state}

Psychological well-being of older adults is enhanced by the forgiveness of others and those who forgive unconditionally are less likely to experience psychological distress (Krause, N., \& Ellison, C. G., 2003). In Hinduism, it is believed that anything that occurs to us is a product of our actions in the past (karma). The revenge will be taken by the law of karma, so we must forgive the person and prevent doing something that will trigger the law of karma. In Christianity, a very important commandment is to love neighbors as one loves oneself. Many bible verses encourage people to let go of bitterness and anger, and forgive people as God forgave their sins. Jesus Christ forgave the ones who slandered and crucified him. In Islam too, forgiveness is a highly valued virtue. They associate forgiveness with controlling one's anger. DeWall, Baumeister, Stillman, \& Gailliot (2007) found that low or impaired self-regulation leads to aggressive behavior. Muslims also believe that since God forgives all imperfect beings, they should also forgive others. In Buddism, forgiveness is a means of saving and letting oneself free of regret and internal conflict. Toussaint and Friedman (2008) found that forgiveness is strongly and positively correlated with well-being.

Religion can be the light at the end of a dark tunnel. It gives hope to continue living while the circumstances prove to be otherwise. Ciarrochi, Heaven and Davies (2007) found that hope significantly 
predicts positive affect and good grades in adolescents. Research done on women diagnosed with breast cancer found that those who scored high on hope experienced less anxiety than the others (Ebright and Lyon, 2002). They also mentioned that they were able to deal positively with treatment because of their religious beliefs.

Gratitude is a virtue highlighted in all religions. The giving of offerings, as discussed earlier, is also a way of saying thanks to God who provided man with wealth and health. In Hinduism, the festival of Pongal also called the harvest festival is a way of thanking God for the produce they make. When one says thanks to God for the produce he makes, he denies ownership by destroying ego and stays humble. In Christianity, thanksgiving is celebrated to inculcate the habit of gratitude. Muslims begin their prayer with gratitude. Kendler et al. (2003) found that religious thankfulness significantly predicts low rates of developing psychiatric disorders. Wood, Maltby, Gillett et al. (2008) found that gratitude decreases the levels of stress over time.

\section{Self-regulation through Discipline}

One of the known exemplars of Bharatanatyam, T. Balasaraswati (1985), says that the tradition allows the dancer to soar in the sky of freedom through discipline. Discipline has been an important teaching in all traditional Indian art forms. Hinduism encourages people to get up before sunrise (brahma muhurta); and do meditation and yoga, which helps to discipline the mind. It was found that high academic performers have the habit of early to bed and early to rise (Eliasson, A. H., Lettieri, C. J., \& Eliasson, A. H., 2010). In Hinduism, youngsters are always taught to give respect to elders and they also touch the feet of elders to get their blessings. In Christianity too, people are always encouraged to give respect to elders and parents, and also to laws and rules. Islam too stresses the importance of giving respect to elders by saying that one who does not respect elders do not belong. This practice helps an individual to stay humble and avoid pride and arrogance.

\section{Self- regulation through Fasting}

Fasting is the act of refraining from food for a period of time. It is highly emphasized in all religions. Hindus fast on different 
weekdays for their God; Christians fast during lent for 40 days and Muslims fast during Ramzan for 30 days. Fasting allows detoxification of body toxins. During this time, the body looks up to fat reserves for energy and thus excess fat is removed from the body, helping people with obesity. During fasting, the energy that's usually spent on digestion is conserved and used for healing of the body, helping patients who undergo chemotherapy. In this manner, fasting comes with a lot of benefits.

\section{Religious self-regulation methods, not final goals}

The Hindu way of life is directed towards the development of intrinsic well-being through the cultivation of certain attitudes, habits, and values that help the process of transformation (Salgame, 2013). According to Kathopnisad, the main purpose of life is explained through the theory of 'purusharthas'. Here 'purush' means atma or self and 'artha' means objectives or goals. There are four main purusharthas - Dharma, Artha, Kama, and Moksha. Artha denotes the things we attain for our survival or security needs. When the things that we attain for artha goes beyond the security needs towards a need of desire and luxury, it becomes kama. Artha and kama are very instinctual so it is not avoided, however, it must be attained through Dharmic ways. Dharma is the value of differentiating between good from bad, and right from wrong. Moksha is the final and ultimate value of Indian tradition; it is liberation of the Atma (self) through self-realization and selfknowledge. Osho says, "Self-realization is coming to no-self, the drop has dissolved into the ocean and only the ocean exists... Self-realization means the complete disappearance of the ego. And with the ego, everything disappears."

Self-regulated living is not the liberation of the soul but rather a means for attaining soul liberation. Dharmic way of life leads to moksha; and self-regulation by an individual helps one in leading a dharmic way of life.

\section{Importance of silence}

Silence is often misunderstood as a cruel method of starving oneself of words or restricting oneself. Rather silence is a method of massive self-control which allows spiritual growth. Silence is also 
confused with mutism, a condition where a person refrains from speech while one is capable of speech due to the anxiety one faces. Here the study does not talk of silence as a result of anxiety. But rather silence here indicates the silence of the mind. Mind keeps ruminating by thinking too much about the past or the future. It is hardly possible to be in the present and experience, as the mind is busy all the time. Through the practice of mouna vratha we silence the organ of speech which will bring silence in the mind and in turn help one to look within oneself.

"The most basic and powerful way to connect to
another person is to listen. Just listen. Perhaps the
most important thing we ever give each other is our
attention. A loving silence often has far more power
to heal and to connect than the most well-
intentioned words."

-Rachel Naomi Remen

Dianna Booher (2015) says excessive talking has the power to kill an idea before it can be executed. This happens because people concentrate on thinking and talking about how promising the future can be rather than doing something to make their future promising. Swami Sivananda (2011) talks about how energy is wasted through excessive talking. He describes excessive talking as a bad habit which distracts the mind and results in the wastage of energy. One must make sure that he/she does not let anything from the mind escape through the vak-indriyas (organ of speech). Practising mouna vratha (vows of silence) once a week, helps in the maintenance of peace and decreasing troubles. The practice also aids in the transformation of speech energy into spiritual energy, therefore, making the person spiritual. Mind exaggerates and creates arguments through imagination. Both exaggeration and argument bring about hostility, in turn resulting in energy wastage, which is wasted spiritual energy. The constant cue at the back of the mind, 'I won't talk', will generate a lot of heat and make the mind to want revenge. To prevent this from happening, one must take the vow of silence and remain quiet. Challenges will come at first through various thoughts invading the mind and force one to give up their vow of silence. However, when one does not give into imagination and trickery of the mind and remains determinant, 
peace will eventually follow. The silence of the vak-indriyas will eventually lead to the silence of the mind leading to eternal peace.

Well-being is more related to having very little small talk and more substantive conversations (Mehl, Vazire, Holleran \& Clark, 2010).

When Osho talks about the nature of the mind he says that psychoanalysis can never be completed even after therapy for five years because mind's infinite capacity keeps on knitting new and new dreams. We keep interpreting and mind starts being more imaginative and creative. He says that mind needs death and not analysis; and that death of mind can happen through meditation (Cunningham, 2012).

In his poem, Khalil Gibran (n.d.) says that we talk when we are not in peace with our thoughts. We live in our lips by talking as we can't live in the silence of our heart. He says beautifully, that thought is the space in the cage of words where the bird can spread its wings but can't fly. He says that people have a fear of silence as it reveals their true self and they escape this by talking too much.

Charlene (2004) talks about the importance of silence in promoting spiritual growth in the compendium of Sai Baba's teachings. Excessive speech harms the mind. The ancients practiced three kinds of silent penance to control speech; One was the silence of the tongue. The second was the silence of the mind. The third was supreme silence. Silence in a speech meant confining one's speech to the limits and the needs of the occasion. By this discipline, the excessive speech was avoided and the power of speech was conserved and enhanced. Discipline in speech also resulted in truthfulness and they acquired realization of truth and realization of the highest wisdom. Therefore purity in speech is vital and it has to be achieved by restraint in speech. Then there is the silence of the mind. The mind is a bundle of thoughts and fancies. These thoughts have to be reduced gradually. When thoughts are reduced, the mind naturally comes under control. When the activity of the mind is reduced, the power of the Atma (self) manifests itself. As a consequence, the intellect becomes more active than the senses. When the control of the speech and the control of the mind have been achieved, the state of supreme silence is actually realized. 


\section{Spiritual practices in Counselling}

Pargament, Exline, Jones, Shafranske \& Mahoney (2013) defined spirituality as "the search for the sacred," with sacred referring to "other aspects of life that are perceived to be manifestations of the divine or imbued with divine-like qualities, such as transcendence, immanence, boundlessness and ultimacy"; they defined religion as "the search for significance that occurs within the context of established institutions that are designed to facilitate spirituality," with significance referring to holistic goals "psychological, social, and physical, as well as those that are spiritual".

The history of psychology has had a very long neglectful approach towards religion and spirituality, even referring to people who are spiritual or religious as psychologically not healthy (e.g., Ellis, 1971; Freud, 1927/1961). However, in recent years, positive psychology has embraced religion and spirituality which has led to a friendly relationship between religion and psychology (Lopez \& Snyder, 2003). Most researchers have come to recognize the connection between faith and health (Koening et al., 2001; Plante \& Sherman, 2001). A study by Richards \& Bergin (2005) shows that there has been a growing interest of people who bring spirituality and religious issues to counselling. Many psychotherapists have now come to believe that addressing clients' spiritual issues sensitively and ably, along with their other concerns, leads to therapeutic success (P. S. Richards \& Bergin, 2004; Sperry \& Shafranske, 2005). Koenig (2008) and Levin, Chatters, \& Joseph (2011) found that religion and spirituality are strongly related to physical as well as the mental well-being of an individual. Park (2012) proposed a model that shows the positive influence of religion and spirituality on healthy behaviour habits and support which may lead to attention diversion and relaxation; it also leads to positive reappraisals and positive states. Krause (2011) took a different approach and argued that religiousness serves the five basic needs indicative of Maslow's hierarchy - the need for self-transcendence, sociality, control, meaning and church attendance. Of all, need for meaning, can affect health positively. Health is affected by religiousness through the arbitration of behavioural self-regulation on health habits; spirituality affects religion through the arbitration of emotional regulation on psychological processes (Levenson \& 
Aldwin, 2013). Yanez et al. (2009) suggested that high levels of religiousness without the component of spirituality may be associated with poor well-being. But according to Spinale et al. (2008), spirituality, without the component of religiousness is connected to survival rates in patients with kidney failure. Chida, Steptoe, \& Powell (2009) suggest that religion and spirituality may have developmental effects than remedial effects i.e., it has positive effects when people are healthy than when people become ill.

\section{Process of Silence}

When speaking of the nature of silence, Odhiambo (2002) says that when we turn away from the sensory inputs and the manipulation of these inputs by the brain, we turn inwards to our own self and turns on the inner thoughts and consciousness. However, it can only be attained when we shut down the sensory inputs and its manipulation by the brain. The resulting silence of the mind opens the key to consciousness and to the soul. This silence of the mind poses a lot of challenges and demands practice. But once acquired, it leads to a completely new dimension of transcendental nature. It is a realization that peace, knowledge of true power and wisdom comes from within the soul. This inner knowledge and peace helps an individual in decision making and gaining knowledge about oneself.

Introspection is the self-reflecting process where one looks within the self and observes oneself - one's thoughts and feelings (Schultz, D. P. \& Schultz, S. E., 2012). In a spiritual perspective, it is often referred to as the self-realization or the observation of one's soul. Silence is an important tool in the process of introspection. Palmer (2000) found that silence helps a person to look within oneself and reflect on oneself. Silence is helpful in detaching oneself from the external situations and through this, they are able to listen to the inner voice and explore their energy and a meaning or purpose in life (Essex and Mainemelis, 2002). This way, silence is helpful to get away from the busy world that surrounds them and thwarts them from exploring their meaning in life (Essex and Mainemelis, 2002), to listen to their inner voice (Whyte, 2001) or discovering one's calling in life (Palmer, 2000). Silence not only helps in turning off 
the external buzz and focusing on the internal voice but also helps in the reflection of oneself (Vince, 2002).

Osho talks about the importance of silence thus "Thinking and dreaming are two aspects of the same thing: during the day while you are awake, it is thinking, and at night while you are asleep, it is dreaming. ...When dreaming stops, thinking stops; when thinking stops, dreaming stops." He says that the entire effort of the East has been an answer to how to let go of the whole thing. In the East, people are concerned not about the adjustment or interpretation of mind but rather about how to let go of the mind. He also acknowledges that the west has now started to realize this as they have begun incorporating the technique of meditation. He says meditation is the way to drop thinking and dreaming and the result is a state which one cannot comprehend or imagine when mind exists (Cunningham, 2012).

\section{Elements of self-regulation}

Zell and Baumeister (2013) portrayed the effect of religion on the four main elements of self- regulation. The four main elements are standards, monitoring willpower and motivation. One needs a sense of direction to exert self-control. Standard is the goal or an idea of what one needs to do. People feel confused when there are conflicting standards with respect to morals. Monitoring is an important aspect of self-regulation. Self- regulation often fails when one has no track of what they do. Increased self-awareness implies increased self-control. Monitoring is a crucial component of selfcontrol (Michie, Abraham, Whittington, McAteer \& Gupta, 2009). Only when people have the power to change their behaviour, standards and monitoring become useful. Thus, willpower becomes the operational element in the regulation of self. Then comes motivation; highly motivated people are more likely to use their resources than de-motivated people (Baumeister \& Vohs, 2007).

Through the silence of speech, one can silence the internal ruminating thoughts and in turn silence the mind. This can be attained through the four main basic processes involved in selfregulation. One must set the standards and monitor oneself; through willpower and motivation, one would be able to regulate 
oneself and go deeper into one's self and attain self-realization. One takes many steps to regulate oneself. Mouna Vratha is one such effective tool in regulating oneself. The setting of standards is setting a goal by taking a vow to maintain silence for about two hours every day. One must also monitor their behaviour by keeping a check on oneself so that one may not break the vow. Willpower is attained in the use of Mouna Vratha, as the power of the word 'Vratha' (Vow) helps an individual to withstand willpower to maintain the practice of Mouna. The final process is motivation. Here is where the weight of the role of a counsellor increases. Initially, the client will need extrinsic motivation from the counsellor to maintain the level of willpower. Gradually, the client develops intrinsic motivation after experiencing the benefits of the practice. The counsellor identifies a minor change in the client and encourages the client to maintain the practice of Mouna Vratha.

\section{Conclusion}

Most of the psychological problems are due to the result of selfregulation failure. Self-regulation helps an individual to be in harmony with oneself. Religious approaches effectively help an individual to develop such self-regulation. The purpose of any religious methods, when applied in a right manner with right understanding and guidance, elevate the performance, transcends the limitations, and attain peace, in order to reach that level one need to follow such practices. One such method is "mouna vratha" or Vow of silence which has been emphasized in most religions and were effectively followed ancient times. This practice has been compared with the Zell and Baumeister (2013) model of Selfregulation which involves Standards, Monitoring, Willpower and Motivation. The use of Mouna vratha as a technique of selfregulation in counselling and psychotherapy will help an individual to explore their selves in the realm of silence. Changes in brain bring about changes in the behaviour of an individual. Likewise, the changes in attitude and behaviour will also lead to positive change in the brain. Though it may take reasonable time and effort, the results will be consistent and help an individual to bring positive brain changes and also elevate oneself spiritually. 
The present paper discussed the effectiveness of self- regulation and how it can be implemented through the practice of mouna vratha. This calls for further research on applying different traditional approaches as intervention and training module for remedial as well as developmental factors of human well-being.

\section{References}

Balasaraswati, T. (1985). The art of Bharata Natyam: a personal statement. In B. T. Jones (ed.), Dance as Cultural Heritage, 2, Dance Research Annual XV, pp. 1-6.

Baumeister, R. (2012). Self-control - the moral muscle. British Psychological Society Journal. 25 (2). 112-115.

Baumeister, R. F., \& Vohs, K. D. (2007). Self-regulation, ego depletion, and motivation. Social and Personality Psychology Compass, 1, 115-128.

Baumeister, Roy F., Todd F. Heatherton, and Dianne M. Tice (1994), Losing Control: How and Why People Fail at Self-Regulation, San Diego, CA: Academic Press.

Booher, D. (2015, Februrary 27). Communication: Excessive Talking Can Be A Killer. Retrieved from http://www.booherresearch.com/communication-excessivetalking-can-killer/

Bormann, J. E., Smith, T. L., Becker, S., Gershwin, M., Pada, L., Grudzinski, A. H., \& Nurmi, E. A. (2005). Efficacy of Frequent Mantram Repetition on Stress, Quality of Life, and Spiritual Well-Being in Veterans A Pilot Study. Journal of Holistic Nursing, 23(4), 395-414.

Carver, C. S., \& Scheier, M. F. (2012). Attention and self-regulation: A control-theory approach to human behavior. Springer Science \& Business Media.

Charlene, L. C. (2004). A compendium of the teachings of Sri Satya Sai Baba.Bangalore: Sai Towers Publishing.

Chida, Y., Steptoe, A., \& Powell, L. H. (2009). Religiosity/ spirituality and mortality. A systematic quantitative review. Psychotherapy and Psychosomatics, 78, 81-90. doi:10.1159/ 000190791. 
Ciarrochi, J., Heaven, P. C., \& Davies, F. (2007). The impact of hope, self-esteem, and attributional style on adolescents' school grades and emotional well-being: A longitudinal study. Journal of Research in Personality, 41(6), 1161-1178.

Cunningham, M. (2012, January 24). Osho - Western Psychology vs. Eastern Spirituality. In End Of The Game. Retrieved from http:// endofthegame.net/2012/01/24/oshos-critique-onwestern-psychology/

DeWall, C. N., Baumeister, R. F., Stillman, T. F., \& Gailliot, M. T. (2007). Violence restrained: Effects of self-regulation and its depletion on aggression. Journal of Experimental Social Psychology, 43(1), 62-76.

Duckworth, A. L., \& Seligman, M. E. (2005). Self-discipline outdoes IQ in predicting academic performance of adolescents. Psychological science, 16(12), 939-944.

Eisenberg, N., \& Zhou, Q. (2000). Regulation from a developmental perspective. Psychological Inquiry, 11(3), 166-171.

Eliasson, A. H., Lettieri, C. J., \& Eliasson, A. H. (2010). Early to bed, early to rise! Sleep habits and academic performance in college students. Sleep and Breathing, 14(1), 71-75.

Ellis, A. (1971). The case against religion: A psychotherapist's view. New York: Institute for Rational Living.

Elson, A., Pearson, C., Jones, C. D., \& Schumacher, E. (1965). Follow-up study of childhood elective mutism. Archives of General Psychiatry,13(2), 182-187.

Essex, E.M., and Mainemelis, C. 2002 'Learning from an artist about organizations: The poetry and prose of David Whyte at work' Journal of Management Inquiry 11(2), 148-159.

Forgas, J. P., Scholar, F. E. E., Baumeister, R. F., \& Tice, D. M. (Eds.). (2011). Psychology of self-regulation: Cognitive, affective, and motivational processes. Taylor \& Francis.

Freud, S. (1961). The future of an illusion (J. Strachey, Ed. and Trans.). New York: Norton. (Original work published 1927)

Gibran, K. (n.d.). On Talking. Retrieved from http:// www.katsandogz.com/ontalking.html 
Hardiman, M. M. (2012). The brain-targeted teaching model for 21stcentury schools. Corwin Press.

Kathopanisad IV.1.

Kendler, K. S., Liu, X. Q., Gardner, C. O., McCullough, M. E., Larson, D., \& Prescott, C. A. (2003). Dimensions of religiosity and their relationship to lifetime psychiatric and substance use disorders. American Journal of Psychiatry, 160, 496-503.

Koenig, H. G. (2008). Concerns about measuring "spirituality" in research. Journal of Nervous and Mental Disease, 196, 349-355. doi:10.1097/NMD.0b013e31816ff796.

Koenig, H. G., McCullough, M. E., \& Larson, D. B. (2001). Handbook of religion and health. New York: Oxford University Press.

Krause, N. (2011). Religion and health: making sense of a disheveled literature. Journal of Religion and Health, 50, 20-35. doi:10.1007/s10943-010-9373-4.

Krause, N., \& Ellison, C. G. (2003). Forgiveness by God, forgiveness of others, and psychological well-being in late life. Journal for the scientific study of religion, 42(1), 77-93.

Kunstler. R. A. \& Daly. F. S. (2010) Therapeutic recreation leadership and programming

Lauencelle, R. M., Abell, S. C. \& Schwartz, D. J. (2002). The relation between intrinsic faith and psychological well-being. International Journal for the Psychology of Religion, 5, 177-180.

Levenson, M. R., \& Aldwin, C. M. (2013). Mindfulness as religious practice. In R. F. Paloutzian \& C. L. Park (Eds.), Handbook of the psychology of religion and spirituality (2nd ed., pp. 580-594). New York: Guilford.

Levin, J., Chatters, L. M., \& Joseph, R. (2011). Theory in religion, aging, and health: An overview. Journal of Religion and Health, 50, 389-406.

Levitt, H. M. (2002). The unsaid in the psychotherapy narrative: Voicing the unvoiced. Counselling Psychology Quarterly, 15(4), 333-350. 
Lopez, S. J., \& Snyder, C. R. (Eds.). (2003). Positive psychological assessment: A handbook of models and measures. Washington, DC: American Psychological Association.

Maltby, J. \& Day, L. (2000). Religious orientations and death obsession. Journal of Genetic Psychology, 116, 122-124.

McCullough, M. E., \& Willoughby, B. L. (2009). Religion, selfregulation, and self-control: Associations, explanations, and implications. Psychological bulletin, 135(1), 69.

McCullough, M. E., Hoyt, W. T., Larson, D. B., Koenig, H. G., \& Thoresen, C. E. (2000). Religious involvement and mortality: A meta-analytic review. Health Psychology, 19, 211-222.

Michie, S., Abraham, C., Whittington, C., McAteer, J., \& Gupta, S. (2009). Effective techniques in healthy eating and physical activity interventions: a meta-regression. Health Psychology, 28(6), 690.

Mischel, W., Shoda, Y., \& Peake, P. K. (1988). The nature of adolescent competencies predicted by preschool delay of gratification. Journal of Personality and Social Psychology, 54, 687696.

Mufti, I. K. (2006, January 16). The Third Pillar of Islam: Compulsory Charity. In The Religion Of Islam. Retrieved November 13, 2015, from http:// www.islamreligion.com/ articles/46/third-pillar-of-islam/

Odhiambo, T. R. (2002). Reconnecting Science with the Power of Silence. The Cultural Values Of Science, 191.

Palmer, P.J. (2000) Let your life speak. San Francisco, CA: JosseyBass.

Pargament, K. I., Mahoney, A., Exline, J. J., Jones, J., \& Shafranske, E. (2013). Envisioning an integrative paradigm for the psychology of religion and spirituality: An introduction to the APA handbook of psychology, religion and spirituality. In K. I. Pargament (Ed.), APA handbook of psychology, religion, and spirituality (Vol. 1, pp. 1-xxx). Washington, DC: American Psychological Association.

Park, C. L. (2012). Meaning, spirituality, and growth: Protective and resilience factors in health and illness. In A. S. Baum, T. A., 
Revenson, \& J. E. Singer (Eds.), Handbook of Health Psychology, (2nd ed., pp. 405-430). New York: Taylor \& Francis.

Plante, T. G., \& Sherman, A. S. (Eds.). (2001). Faith and health: Psychological perspectives. New York: Guilford Press.

Richards, P. S., \& Bergin, A. E. (2004). Casebook for a spiritual strategy in counseling and psychotherapy. Washington, DC: American Psychological Association.

Richards, P. S.,\& Bergin, A. E. (2005). A spiritual strategy for counseling and psychotherapy (2nd ed.). Washington, DC: American Psychological Association.

Salagame, K. K. (2013, January). Well-being from the Hindu/Sanātana Dharma Perspective. Oxford Handbook of Happiness.

Sardello, R. J., \& Sanders-Sardello, C. (2008). Silence: The mystery of wholeness. North Atlantic Books.

Schultz, D. P. \& Schultz, S. E. (2012).A history of modern psychology (10th ed.). Belmont, CA: Wadsworth, Cengage Learning. pp.67$77,88-100$

Sivananda, S. (2011). Mouna and Introspection. In The Divine Life society. Retrieved from http://www.sivanandaonline.org/ public_html/?cmd=displaysection§ion_id=896

Sperry, L., \& Shafranske, E. P. (Eds.). (2005). Spiritually oriented psychotherapy. Washington, DC: American Psychological Association.

Toussaint, L., \& Friedman, P. (2009). Forgiveness, gratitude, and well-being: The mediating role of affect and beliefs. Journal of Happiness Studies, 10(6), 635-654.

Vince, R. (2002). 'Organizing Reflection' Management Learning 33/1: 63-78.

Weaver, A. J., \& Flannelly, K. J. (2004). The role of religion/spirituality for cancer patients and their caregivers. Southern Medical Journal, 97(12), 1210-1214.

Whyte, D. (2001). Crossing the unknown sea. New York: Riverhead Books.

Wood, A. M., Maltby, J., Gillett, R., Linley, P. A., \& Joseph, S. (2008). The role of gratitude in the development of social 
support, stress, and depression: Two longitudinal studies. Journal of Research in Personality, 42, 854-871.

Yanez, B., Edmondson, D., Stanton, A. L., Park, C. L., Kwan, L., Ganz, P. A., \& Blank, T. O. (2009). Facets of spirituality as predictors of adjustment to cancer: Relative contributions of having faith and finding meaning. Journal of Consulting and Clinical Psychology, 77, 730- 741.

Zubko, A. (1996). Treasury of spiritual wisdom: a collection of 10,000 powerful quotations for transforming your life (428-442). New Delhi, India: Motilal Banarsidass Publishers Pvt. Ltd. 